\title{
The Role of Non-State Actors in Strengthening the Developmental Capacity of the State: A Case Study of Cross Rivers State, Nigeria
}

\author{
Felix Chukwudi Oparah \\ Department Of Economics, University Of Calabar, Calabar, Nigeria \\ Enya Ndem Bassey (Phd) \\ Department Of Economics, University Of Calabar, Pmb 1115, Calabar, Nigeria \\ Ohatu Ekoh Ohatu \\ Department Of Economics, University Of Calabar, Calabar, Nigeria \\ Email: Ndembassey1@Gmail.Com
}

Received: February 13, 2020

Accepted: March 3, 2020 Published: April 23, 2020

doi:10.5296/ber.v10i2.16447

URL: https://doi.org/10.5296/ber.v10i2.16447

\begin{abstract}
This study examined the role of Non State Actors (NSAs) in strengthening the developmental capacity of the state, using a case study of Cross River State, Nigeria. Primary and secondary data on selected constituents of NSAs including Non Governmental Organizations (NGOs), Privately Owned Companies, Banks, Private Hospitals and Private Schools were analyzed using tables and charts. The results revealed that activities of NSAs significantly enhance the developmental capacity of Cross River State especially in the areas of provision of public services, knowledge and skill acquisition, infrastructural development and employment generation. Besides other recommendations, it was recommended that NSAs and the government should perform complementary roles in enhancing developmental capacity and that the establishment of more NSAs in the rural areas should be encouraged through the provision of special funding and other incentives for NSAs that have their offices in the rural areas.
\end{abstract}

Keywords: Non State Actors, Developmental capacity, NGOs, Cross River State 


\section{Introduction}

The activities of Non-State Actors (NSAs) in promoting the development of states and nations have become of increased importance in recent times. It is generally believed that the process of building an efficient and effective service oriented developed state requires the participation of both the government and NSAs. Many economists and analysts believe that NSAs activities should be complementary to that of the state. NSAs require good working relationship and cooperation with the government. (Essia and Yearoo, 2009).

In a predominantly capitalist economy, the role of the government is mostly limited to the provision of conducive political and economic environment, security, public infrastructure, public goods and services and other social amenities. It is widely accepted that the state is primarily concerned with the well being of its citizens. Invariably, this requires both human and financial resources. The major issues facing the government are the extent and diversity of services to be provided so as to satisfy the needs of its citizens. Due to the complexity and diversity of services required by the citizens of a state, and given that most states in Nigeria do not have the technical, human resources and financial muscles required to provide services that could be said to be efficient and effective to the public, the government is compelled to collaborate with the private sector in the provision of public goods.

NSAs are involved in the provision of basic services like education, security, health care, infrastructural development, water supply, etc. Hence, the provision of these basic services which normally should be within the coverage of the state also falls within the operational areas of NSAs. They also organize capacity development programs in form of training, skill acquisition and informal educational programs for citizens of their areas of coverage. Whereas there is a simple correlation between weak development capacity and NSAs' involvement, the need for both entities to work collaboratively should be emphasized with a view to enhancing the developmental prowess of the state.

In Cross River State, developmental strategies of the state government over the years have been hampered by corruption, institutional incapability, inadequate funding and lack of technological wherewithal. Furthermore, the dwindling federal allocation (owing to fall in oil prices), inadequate internally generated revenue and huge debt burden have left the state with no other option than to look for development partners. Public-private partnership and privatization of government owned corporations have been introduced to see whether the state could remain on the path of sustainable development as well as deliver effective and efficient service to its teeming residents. However, host communities of some government owned projects and privatized corporations have perceived some of these moves as retrogressive, corruption infested, lacking in merit and devoid of due process. In some cases, some of these projects have been rejected by the host communities.

Despite the continued distrust that is prevalent between governments and NSAs, there is clearly room for both to work in harmony in bringing about changes for the better in the lives of the citizens. They can learn to co-exist and find a mutual ground for their work. NSAs cannot displace government because the role of the government cannot be precluded and similarly the government cannot cover all aspect of governance and development. 
The size of the public sector is small in human, material and technological resources required to cater for the well being of the entire citizens of the state. Hence, it is our view that all developmental stakeholders (including the government and NSAs) should work together to achieve great developmental strides and effective/efficient service delivery in the state

In Cross River State, most of the services provided by the government are usually marred by inefficiencies and absence of effective planning and implementation. Others do not have the required depth and coverage required especially in relation to rural dwellers. This is usually due to inadequate capacity development and lack of institutional, technical and professional competence. Having seen the gap in service provision and the inefficiencies and ineffectiveness associated with the provision of public goods by the government, NSAs have introduced different programs such as training, skill acquisition, corporate social responsibilities, public enlightenment etc for the citizens of the state both in the urban and rural communities with a view to enhancing the developmental capacity of the state and ensuring effective and efficient service delivery. They have also been involved in direct provision of several basic services in the educational, health, infrastructural and other sectors of the state. However, the quality of public goods and services in the state and the general quality of life have continually remained poor.

Based on the foregoing, this study seeks to evaluate the relationship between activities of NSAs in Cross Rivers State and the developmental capacity of the state. Specifically, we shall examine the following:

1. The involvement of NSAs in training, skill acquisition and public enlightenment programs in the state and its impact on the developmental capacity of the state.

2. The impact of corporate social responsibility of NSAs on the development of the state.

3. The performance of NSAs in terms of direct provision of public service such as education, health, water, infrastructural development, etc in the state.

The outcome of this research will help the state appraise its strategy, focus and relationship with NSAs towards developmental capacity enhancement and efficient service delivery. It will also help NSAs to reposition themselves on the track for enhanced performance in the state. Furthermore, it will form the underpinning for further action plans for all the stakeholders in the state and in the country in general, towards ensuring sustained development in all areas.

\section{Literature Review and Theoretical Framework}

\subsection{Literature Review}

Generally speaking, the process of enhancing the developmental capacity of the state requires the involvement of all stakeholders. An effective and efficient state is one that has the qualities of a contemporary, strong, dependable and responsive state; proficient in effectively discharging its duties to the general public. Although the state has traditionally been regarded as the anchor point of public service provision, other stakeholders including NSAs have 
important roles to play in this regard. The importance of this role has grown significantly over the past years as the limitations of the state in providing the basic needs of its citizens have become more evident. Mabogunje, (2000).

In their study on the rise of NSAs in international authority, Thomas et al (2013) noted that the growth in NSAs represents a shift in providing solutions to the issues on why and how the world gains from global governance but the developing system is in disequilibrium. The variety of actors has created opportunities for new relationships to be formed and older ones fortified.

In their study on states' capacity and NSAs in weak and conflict affect states, Richard and Claire (2009) attempted to show how states with weak capacity can effectively fulfill the indirect service provider roles. They posited that whereas there is a simple correlation between levels of state developmental capacity and levels of NSAs service provision, state weakness can result in parallel systems of NSAs participation which are disjointed and uneven. They concluded that most NSAs operate free from any methodical government interference, harmonization or oversight in a delicate and weak state.

In his views Jenerali (2005) noted that due to the obvious constraints that the government is faced in ensuring enhanced developmental capacity for the state, there is urgent need for NSAs to contribute towards ensuring a capable state. He defined a capable state as one that has all the trappings of a modern, strong, responsible and responsive state; a state with the ability to effectively perform its duties to the citizens. He concluded that NSAs should play a vital role in the areas of peace, security, safety, infrastructure and the provision of other public goods especially in areas where issues of insecurity has undermined the developmental capacity of the state.

Ladipo (2011) defined NSAs involvement in terms of public-private partnerships (PPP). In his views, many countries including Nigeria have committed to implementing a significant number of projects and programs through PPP. In most cases the aim of the government is to attract finance and technical/managerial expertise, especially in the infrastructural and social sector. He noted that although some PPPs witnessed major obstacles across the world during the recent financial crises (2008-2010) with the shattered private sector unable to deliver in respect of prior commitments, governments in many countries have continued to embrace PPPs as a desirable tool for implementing development projects. He concluded that there is need to involve the private sector especially large corporate entities, small and medium size enterprises (SMEs), cooperative societies, social enterprises and voluntary organizations in the capacity developmental processes of the state.

Similarly, Anshul et al.(2010), believe that a partnership between government and NSAs can raise consciousness, support for government policies and promote a responsible system of development planning and execution. However, they noted that this entails dedicated relationship and trust from both sides. They held that the capacity and willingness of NSAs influence the potential for successful partnership between both parties towards enhancing the development of the state. 
The capacity of NSAs on technical, human and financial resources grounds to carry out their operations in a significant scale affects the level of impact they will make on developmental capacity. This was enunciated by Essia and Yearoo (2009) when they posited that building sustainable collaboration between government and NSA is a key requirement for resolving the apparent quagmire of poverty, unemployment, crumbling institutions and other attributes of underdevelopment that characterized the country, Nigeria. They concluded that the effectiveness of the NSAs depends on their capacity and the institutional mechanism that exist for their active involvement in the development of the country.

The growth of NSAs in Nigeria over the last two decades especially with the advent of democracy in 1998 has elicited huge interests from many analysts and writers. This has ignited general awareness and interest in this area as could be seen from the fore-going. However, there is dearth of scholarly work on specific regions and states in the country especially in the south-south geo-political areas where there is weak developmental capacity due to inadequate infrastructural base, over dependence on the federal government and general weak internal base. Thus, the need for this work.

\subsection{Relationship between NSAs and the Cross River Rivers State Government}

The interactions between NSAs and the successive governments of the geographical area called Cross Rivers State dates back to centuries ago. The phenomenon of NSAs started with the appearance of private societies or entities with public interest in the late 18th century. The creation of issue based NGOs against slavery and poverty started with small groups of citizens becoming aware of moral and social problems. They combined their critical disposition with the belief that part of the solution was to form larger groups and associations. As the groups became larger and strengthened by the presence of enlightened and well educated members, they become more vocal and ventured into several areas of the political and socio-economic environment. This saw them form strong pressure groups against unpopular government policy as well as contributing positively in governance by being involved in direct public service provision.

In Cross River Stat, decisions taken by NSAs affect the workings of the state government. For example, an industrial action by the Nigeria Labour Congress (NLC) will always paralyze activities of the state government. It is on record that several industrial strike actions by the NLC left various government offices under lock and keys. On the other hand, a decision by NSAs to support a particular government policy could make the policy very popular.

An NSA organization, for example, a trade union can enter into discussion with the government in the interest of its members and the public in general. Trade unions usually go to the discussion table with good negotiation grounds and strong negotiation skills. These confer to them strong bargaining power.

It has been observed that for any government policy to have the desired effectiveness, stakeholders' inputs are usually required. Therefore, the government usually consults the relevant NSA organizations in its policy development and implementation. NSA 
organizations like the chambers of commerce/the organized private sector, Academic Staff Union of Universities, NLC, NGOs and other relevant stakeholders are usually consulted for input before the introduction of any major policy shift by the government.

\subsection{The Concept of Non State Actors}

The nomenclature, Non State Actors is used to refer to a wide range of development participants other than governments. It consists of the private sector and all economic and social collaborators including the civil society and trade union organisations in all forms and varieties, Biodun et al (2005). This means that involvement is open to all kind of actors, such as the private sector, community-based organisations, cultural groups, human rights organizations, non-governmental organisations (NGOs), religious bodies, cooperative societies, trade unions, town unions, private universities, research institutes, private schools, etc.

Many literatures have identified several entities as constituents of NSAs. However, we have provided below, an in depth (although not exhaustive) listing of entities that constitute NSAs in Nigeria and as applicable to our study:

\subsubsection{The Private Sector}

This subsector comprises a lot of actors, mainly involved in profit-oriented endeavors in commercial, trading, oil and gas exploration, farming, mining, and other areas. Its importance has grown dramatically since the emergence of democratic rule in Nigeria with the attendant economic empowerment programs of successive government. It ranges from large corporate entities and oil giants, to small and medium scale entrepreneurial actors who provide gainful employment to a large number of citizens. It also includes craftsmen, artisans, petty traders, hawkers and other similar private operators who are involved in one form of business endeavor or another. The private sector is continually assuming a prominent role in the provision of many services that were previously preserved for the government, as we observe the current economic redirection of many states in Nigeria which has seen government withdrawal from direct economic activities (evidenced by the privatization of many government owned corporations) and service delivery.

\subsubsection{Civil Society Organizations}

It is generally believed that the Civil Society refers to an aggregation of entities and organizations that interact with the government, the business circle and the household. They usually pursue the interest of the populace and seek to implement social norms, etc. Some of these organizations are discussed below:

\subsubsection{Non Governmental Organizations (NGOs):}

These are one of the most visible constituents of NSAs. It is regarded as the largest and oldest in terms of coverage and number of members. They are mostly engaged either in capacity development activities or in advocacy activities. However, they seem to be limited in scope and operate in small geographical areas, mostly attracting small groups of people. In right advocacy, their activities are usually manifest in areas such as sanitation, community poverty, 
women and children rights, HIV awareness, etc. Some are involved in more complex issues like gender inequality, human rights, poverty reduction, economic empowerment as well as social and political empowerment.

\subsubsection{The Media}

The media is one of the most influential actors in governance in Cross Rivers State. Its activities have grown tremendously in the last decade especially with the passage of the Freedom of Information Bill in to law in May, 2011 and the opening up of the media industry which gave rise to the emergence of many privately owned radio, television and print media houses. This has destroyed the monopoly of the over the sources and content of information. Furthermore, the growth of online and social media has made the media a strong NSA in Cross Rivers State. This new media reality has been instrumental in sensitizing public opinion against corruption, graft, public theft as well as promoting government policies and programs.

\subsubsection{Cooperative Societies}

These are non profit oriented organizations formed by the pooling together of resources to the benefits of individual members. They are majorly found within the low and middle income earning groups both in the rural and urban areas. They include farmers' cooperatives, traders' cooperatives, financial cooperatives, credit and thrift cooperatives, etc.

\subsubsection{Faith-based and Religious Organizations}

These are organizations that are structured around a common belief in a supreme being and shared interest. They help members of their congregations to get together and pool resources, including sharing ideas to tackle common problems. There are also involved in activities such as training in basic trades and skills, educational services, health services and well as community based services like sanitation, water supply, etc. They also tend to support the poor in the community through donation of household items and charity. Their basic financial sustenance is guaranteed by the contribution of their members. They include churches, mosques, missionary institutions, etc.

\subsubsection{Trade Unions}

These are conventionally the most powerful of all civil society organizations. They form the crux of the social forces engaged in the quest to establish the limits of governance and to check unpopular government policies and programs. They are a strong pressure group in checking government excesses and employ instruments of strikes, boycott, picketing etc to enforce their views and opinions.

\subsubsection{Commercial Associations}

Their activities include advising the government on how to help them develop their industries in consonance with the interests of other sectors of the society, as well as in the promotion of self-regulation. The importance of these associations arises out of their centrality in the productive or real sectors. They include, chambers of commerce, agriculture, manufacture, 
mining etc who play important roles in economic governance

\subsubsection{Professional Associations}

These are organizations representing professionals and introduce the views of their members and experiences to the knowledge of government with a view to influencing government policies.

These professional bodies include: The Nigerian Bar Association, The Institute of Chartered Accountants of Nigeria, Nigerian Medical Association, etc. They play a crucial role in ensuring that their members perform their duties diligently, with probity and in checking professional misconduct and sanctioning fraud. They are of special importance in promoting self-regulation in areas in which governmental agencies/bodies lack competence.

\subsubsection{The Academia and Students' Organizations}

These are among the most expressive members of civil society, supported by their relative youthfulness and high experience. However, in many cases, they have been more confrontational with the government, which has led to frequent closures of many higher institutions in the state. The academia has made great impact and contribution towards government policies and actions. However, they have been undermined by the quest for attractive consultancy jobs and advisory roles, usually commissioned by the government. These activities reduces the time for serious academic work and also lead to intellectual compromise and compromise of standards and ethics.

\subsubsection{Cultural Associations and Community groups}

These are majorly found in the rural communities and seek to project the interest of the rural populace. They are mostly informally organized and in many instances have had to contend with centralizing tendencies of the government that have tried to suppress them, having viewed them as tribal and, therefore parochially jingoistic and divisive.

\subsection{Theoretical Framework}

The theoretical underpinning of this study is the theory of Capacity development. The general perception that has dominated development thought for many years since the inception of international development cooperation has been that the main promoters of economic development were capital and technology (skills and technology). It is upon these foundations that development assistance from foreign bodies/countries grew along two major areas: aid and technical cooperation.

Capacity development is the procedure by which individuals, organizations and societies acquire, fortify and sustain the ability to establish and achieve their own development objectives over time. (UNDP, 2005). Capacity development is about, procedures, systems, skills and institutions. It is about sustaining growth - with individuals, groups and across societies as a whole.

There is a general agreement that capacity cannot be detached from sustainable development; it is capacity that generates the ingredients for development. There is also a growing 


\section{Macrothink}

Business and Economic Research

ISSN 2162-4860

2020, Vol. 10, No. 2

understanding that capacity should be considered from three perspectives: the individual, institutions and environment

In Cross River State, there is the need for a system of developing and integrating the individual skills/knowledge, and organizational structures at the basic service provision levels (both for the private and public sectors-) and the enabling environment in order to achieve sustained developmental objectives of the state. Citizens of the states deserve to be given better services at both the private, state and local government levels

\section{Study Area}

This work is focused primarily on Cross River state, Nigeria. The involvement of NSAs in the developmental efforts of the state spans across diverse areas including, education, health services, infrastructural development, tourism, entertainment, youth empowerment, security and peace, etc. We will evaluate the activities of different NSA organizations in the different local government areas that constitute the state.

Cross River State is a state in south-south geo-political region and it is situated in the Niger Delta area of Nigeria. Its capital is Calabar and other major towns include Ikom, Ugep, Akamkpa, Ogoja Odukpani, and Obudu. It has 18 local government areas. The major occupation of the people of the state is agriculture and this provides employment for many school leavers and graduates of higher institutions. The agricultural activities in the state include farming, fishing, livestock rearing, etc. The state is also very popular in cultural festivities prominent among which is the annual Calabar carnival.

\section{Research Methodology}

This study adopted both the qualitative and quantitative research methods. Primary and secondary data obtained from the state ministries/departments and NSA organizations were analyzed using tables and charts. The secondary data were obtained from the relevant state ministries/parastatals/agencies (MDAs) of the state government while the primary data were obtained from direct enumeration and interviews with staff of selected NSAs organizations. The selection was done randomly. The NGOs, Private Companies, Banks, Private Schools, Private hospitals and FBOs were used for the study. 


\subsection{Data Presentation and Analysis of Results}

Table 1. The distribution of NGOs by LGAs in Cross River State as at July 2018

\begin{tabular}{|c|c|c|c|c|c|}
\hline $\mathrm{S} / \mathrm{N}$ & $\begin{array}{l}\text { NO OF } \\
\text { LGAs IN } \\
\text { THE STATE }\end{array}$ & $\begin{array}{l}\text { NO OF } \\
\text { APPROVED } \\
\text { NGOs }\end{array}$ & $\begin{array}{l}\text { NO OF } \\
\text { REGISTERED } \\
\text { PRIVATE HOSPITALS }\end{array}$ & $\begin{array}{l}\text { NO OF } \\
\text { BANKS }\end{array}$ & $\begin{array}{l}\text { NO OF } \\
\text { REGISTERED } \\
\text { PRIVATE SCHOOLS }\end{array}$ \\
\hline 1 & Abi & 1 & 1 & 1 & 8 \\
\hline 2 & Akamkpa & 1 & 3 & 1 & 11 \\
\hline 3 & Akpabuyo & 1 & 1 & 0 & 3 \\
\hline 4 & Bakassi & 2 & 0 & 0 & 1 \\
\hline 5 & Bekwarra & 1 & 2 & 0 & 23 \\
\hline 6 & Biase & 2 & 2 & 0 & 11 \\
\hline 7 & Boki & 4 & 4 & 0 & 18 \\
\hline 8 & Calabar Municipal & 74 & 43 & 31 & 33 \\
\hline 9 & Calabar South & 33 & 34 & 5 & 28 \\
\hline 10 & Etung & 2 & 0 & 0 & 7 \\
\hline 11 & Ikom & 12 & 15 & 5 & 38 \\
\hline 12 & Obanliku & 4 & 3 & 1 & 8 \\
\hline 13 & Obubra & 2 & 3 & 0 & 30 \\
\hline 14 & Obudu & 7 & 5 & 3 & 24 \\
\hline 15 & Odukpani & 1 & 1 & 0 & 4 \\
\hline 16 & Ogoja & 9 & 6 & 5 & 35 \\
\hline 17 & Yakuur & 6 & 6 & 2 & 26 \\
\hline \multirow[t]{2}{*}{18} & Yala & 4 & 1 & 0 & 42 \\
\hline & TOTAL & 166 & 130 & 54 & 350 \\
\hline
\end{tabular}

Source: Data from the Dept of Civil Society and NGOs, River State; Cross River State Ministry of Health, Cross River State Ministry of Education; and Author's enumeration and compilation.

A chart showing the distribution of NASs by LGAs in Cross River State as at July 2018 


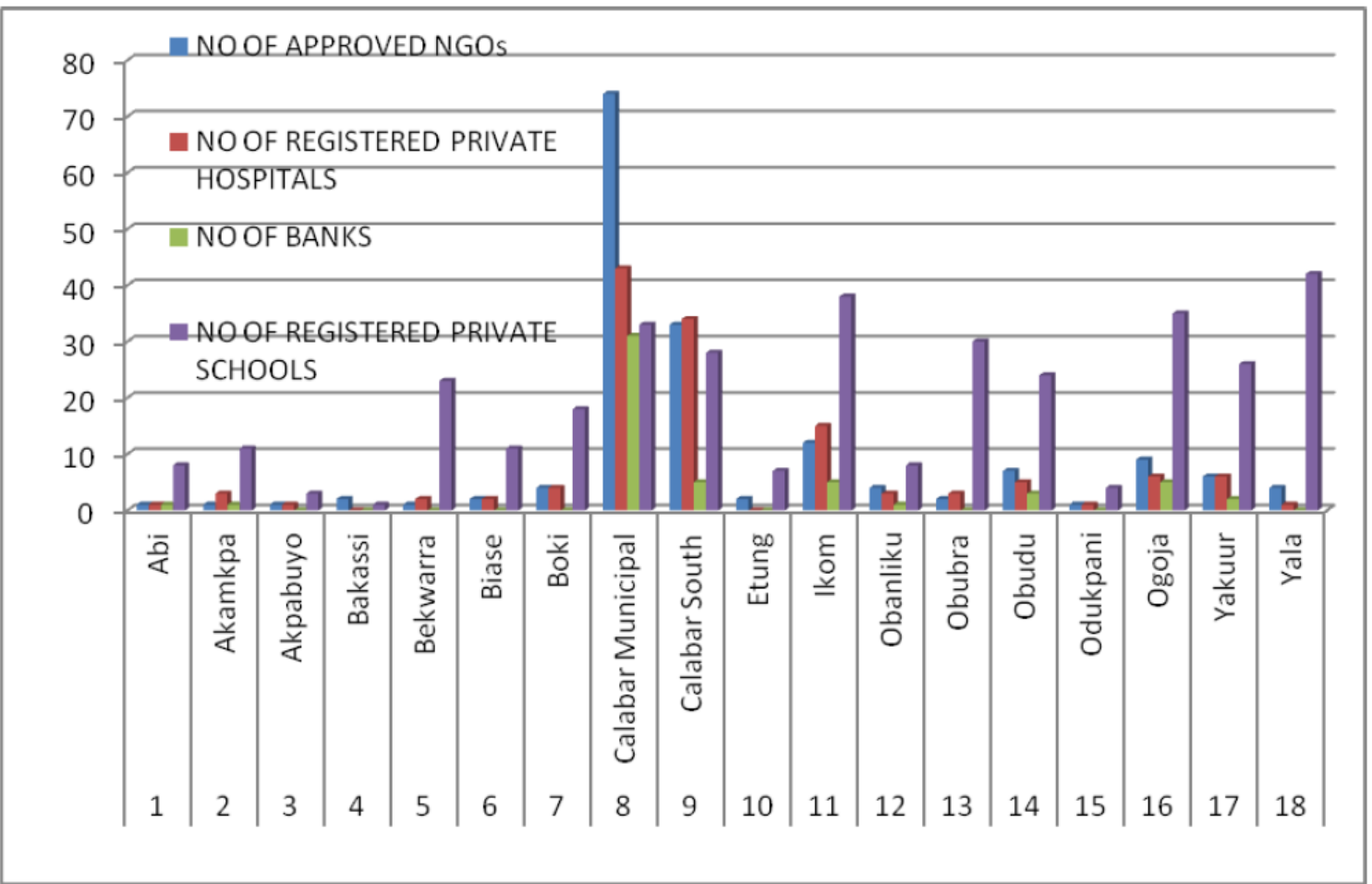

Source: Authors computation.

Table 2. A cross-section of companies operating in different areas of specialization across different LGAs in the state

\begin{tabular}{|l|l|l|l|}
\hline S/N & Name of company & Project site/office location (lga) & Industry/specialization \\
\hline 1 & Crushed Rock Industries Ltd & Akamkpa & Quarry \\
\hline 2 & Transcorp Group & Calabar Munincipal & Hospitality \\
\hline 3 & Wilmar Intl Ltd & Akamkpa/Biase & Oil Palm/Agriculture \\
\hline 4 & African Sun Ltd & Obudu/Calabar Munincipal & Hospitality \\
\hline 5 & Dangote Group & Calabar Munincipal/Odukpani & Flour/Cement \\
\hline 6 & Prodeco Nigeria Ltd & Akamkpa & Quarry \\
\hline 7 & PZ Cussons Nig Plc & Biase & Oil Palm/Agriculture \\
\hline 8 & Flour Mills Nig Plc & Akamkpa & Cement \\
\hline 9 & Northwest Petroleum and & Calabar Municipal & Oil and gas \\
\hline 10 & United Cement Coy of Nig Ltd & Calabar Municipal/Akamkpa & Cement \\
\hline 11 & CCECC Nig Limited & Calabar Municipal/Yakurr & Construction \\
\hline 12 & Arab Contractors Ltd & Calabar Municipal & Construction \\
\hline 13 & Essar Power Ltd & Odukpani & Power generation \\
\hline 14 & PAMOL Nigeria Limited & Calabar Municipal/Odukpani & Rubber/Oil Palm \\
\hline 15 & Banks & Calabar South \& Municipal,Ikom, Ogoja & Banking \\
\hline
\end{tabular}

Source: Survey by Author 
Table 1 and the chart above show the following:

1. The total number of registered NGOs in the state is 166 , private hospitals 129 , banks 54, while private schools are 350.

2. Calabar Municipal LGA has the highest number of NGOs, private hospitals and banks with $74,43,31$ respectively while it came $4^{\text {th }}$ in number of private schools with 33 schools.

3. This is followed by Calabar south with 33, 34, 5 in NGOs, private hospital and banks, respectively. However, it came $6^{\text {th }}$ in number of private schools with 28 schools.

4. Yala LGA has the highest number of private schools with 42 schools.

5. Other local governments which recorded relatively high numbers are: Ikom, Ogoja, Obudu and Yakurr.

6. A total of nine (9) LGAs including Akpabuyo, Bakassi, Bekwara, Biase, Boki, Etung, Obubra, Odukpani and Yala do not have any bank located in them.

7. Two (2) LGAs, Akpabuyo and Bakassi do have any registered private hospital located in them.

8. Abi, Akamkpa, Akpabuyo, Bekwara, and Odukpani have the lowest number of NGOs with one (1) NGO in each.

9. A greater number of the NSAs are located in the capital city of Calabar city (Calabar Municipal and Calabar South LGAs).

10. Most of the NSAs are based in the urban areas given the figures recorded for Calabar Municipal, Calabar South, Ikom, Ogoja and Obudu local government areas.

11. Based on our interviews with the staff of the Department of Civil Society and NGos, other relevant MDAs in the state and staff of selected NGOs in the state including Action for Rural Development (AFRUD) and Women, Youth and Children Upliftment Foundation (WYCUT), we noted the following:

a. Most of the NGOs in the state are involved in one form of capacity development program or the other in terms of training and skill acquisition programs. These trainings usually cover areas such as HIV/AIDS, sanitation, safety, sexual health, leadership, environment, economic empowerment, transparency \& accountability, good governance etc.

b. Although most of the NGOs are based in the cities, many of their programs are targeted at the rural dwellers and hence sited in the villages and communities. For example, AFRUD whose office is in Calabar Municipal LGA organized a training program on harmful traditional practices/HIV \& AIDS for youths in OGADA village in Obubra LGA in April, 2013. It also organized a Community Led Total Sanitation (CLTS) program for 34 communities in Busi ward, Obanliku LGA of the state between January and February, 2015. 
12. Based on our survey on the private sector sub-sector of NSA (see table 2 above), we noted the following:

a. Several companies and multinational are operating in different industries in the state. These companies, through their daily operations are involved in strengthening the developmental capacity of the state. Their activities generate employment for many citizens of the state as well as through backward and forward integration. They also embark on infrastructure development like building of local roads, electricity, water, housing etc. Skilled and semi-skilled workers are also produced through their various training and skill acquisition programs for the local populace.

b. As part of their corporate social responsibility, these companies contribute to the development of the state. For example, in 2013, Northwest Petroleum and Gas Company Ltd embarked on renovation of St. Augustine Primary School Ikot Omin, Calabar and transformed the school from a rural primary school with dearth of facilities into a modern learning centre with the state of the art facilities. Furthermore, in 2014, United Cement Company Ltd (Unicem) commissioned two educational development programs in Akwa-Ikot Effang, Akpabuyo LGA and Mbobui in Akamkpa LGA. The projects are a four room self -contain Teachers' Quarters at Mbobui Primary School built to provide accommodation for Primary school teachers and a twin 2 bedroom flat as Corps Members' Lodge at Government Comprehensive Secondary School, Akwa-Ikot Effanga community also built to provide accommodation for Corps Members posted to the community on National Youth Service.

13. Banks sponsor many developmental projects in the state for example, the Annual Calabar Cannival.

14. Several Faith-Based Organizations (FBOs) are scattered across the different LGAs of the state. However, they are more concentrated in the urban cities of Calabar, Ikom and Ogoja. They include different churches and mosques found in almost all the streets of Calabar and other major cities of the state. They also include other religious bodies. They are involved in community development programs like sanitation, provision of educational and health services like schools, universities, hospitals etc.

The findings as enumerated above negate the three hypotheses maintained in this study. It is therefore revealed that NSAs in the state contribute significantly in strengthening the developmental capacity of the state.

\section{Conclusion and Recommendation}

The study evaluated the role of NSAs in strengthening the developmental capacity of the state, using a case study of Cross River State. In the study, we examined the NGOs, private hospitals, banks and private schools across the state. The study revealed that activities of NSAs significantly affected developmental capacity of the state and hence, contributed to enhancing the effectiveness and efficiency of service delivery in the state. 
Based on the study, we recommend the following:

a. The government and NSAs should perform complementary roles in capacity development in the state.

b. There is an urgent need to encourage the establishment of more NSAs in rural areas to ensure enhanced participation by the local populace in developmental activities. This could be done through providing special funding for NSAs that have their offices in the rural areas.

c. There should be more collaborative efforts and strategy sharing among NSAs so as to promote the effectiveness and efficiency of their programs and avoid overlapping roles.

d. Determination and allocation of training/skill acquisition and developmental programs should be based on societal needs and not politically motivated or based on selfish needs.

e. The state should create more enabling environment for NSAs especially the private sector through goal oriented laws, tax incentives/holidays etc.

f. Provision of basic infrastructure like power and roads by the government will encourage the NSAs to further drive their efforts towards sustainable development.

g. On the part of the government specifically, efficiency and effectiveness of public services rendered by it should entail the following:

a. Establishing adequate institutional framework and structures at all service points and levels.

b. Prioritizing needs: the most crucial needs have to be satisfied first

c. Sound management systems and practices: eliminate bureaucratic bottlenecks and wastages

d. Transparency and accountability. This will mostly prevent inequitable allocation of resources and corruption.

e. Good ethical conduct for government officials and employees

f. The use of modern equipment and experts

g. Adequate supervision and monitoring

h. High motivation and improved condition of service

\section{References}

Biodun, O., Sheriffdeen, T., \& Bruno, V. (2000). Non State Actors under the current ACP-EU cooperation agreement: A sectoral review of the Nigerian Contex. ISSM working papers.

Ikharehon, J. I. (2007). Capacity building for national sustainable development. The Nigerian 
experience. Journal of Social Sciences, 15(1), 25-29.

https://doi.org/10.1080/09718923.2007.11892558

Jererali, U. (2005). The Role of Non State Actors. Paper Presented in the 7th African Governance Forum on Building the Capable State of Africa. UNDP.

Mabogunje, A. L. (2000). Institutional Radicalization, the state and development process in Africa. Development Policy Centre, Ibadan. https://doi.org/10.1073/pnas.200298097

Omodia, M. (2009). Manpower Development in Nigeria: Conceptual and Methodological Perspectives. Journal of Social Sciences, 18(2), 113-117.

https://doi.org/10.1080/09718923.2009.11892671

Richard, B., \& Claire, M. (2000). GSCDRE governance and social Development Resource Centre Publication.

SANSOM, K. (2006). Government Engagement with Non-State Providers of Water and Sanitation Services. Public Administration and Development, 26, 207-217.

https://doi.org/10.1002/pad.419

Teamey, K., \& Mcloughlin, C. (2009). Understanding the Dynamics of Relationships between Government Agencies and Non-state providers of Basis Services; Key Issues Emerging from the Literature. NGPA Research Paper 30, London School of Economics.

Soderlund, N, et al. (Eds), (2003). The new public-private mix in health: exploring the changing landscape. Geneva: Alliance for Health Policy and Systems Research.

Thomas, G., Conor, S., \& Kelsey, C. (2013). The Rise of Non State Actors in Global Governance- opportunities and limitations. A One Earth Future Discussion Paper.

UNDP (2005). Capacity Development Practice Note.

Uwem, E., \& Afzal, Y. (2009). Strengthening civil society organizations/government partnership in Nigeria. International NGO Journal, 4(9), 368-374.

\section{Copyright Disclaimer}

Copyright for this article is retained by the author(s), with first publication rights granted to the journal.

This is an open-access article distributed under the terms and conditions of the Creative Commons Attribution license (http://creativecommons.org/licenses/by/4.0/). 